\title{
A Cluster Project Approach to Develop New Functional Dairy Products from Sheep and Goat Milk
}

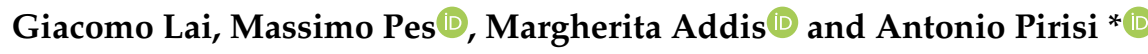 \\ Agris Sardegna, Loc. Bonassai, 07040 Olmedo (SS), Italy; gialai@agrisricerca.it (G.L.); mpes@agrisricerca.it (M.P.); \\ maddis@agrisricerca.it (M.A.) \\ * Correspondence: apirisi@agrisricerca.it; Tel.: +39-079-2842391
}

Received: 21 July 2020; Accepted: 2 September 2020; Published: 7 September 2020

\begin{abstract}
The growing scientific interest in the role of food in promoting human health and wellbeing has profoundly influenced consumers' perceptions and attitudes towards nutrition, leading to the advent of a new class of foods, called functional foods, which are currently one of the fastest growing food-producing sectors, particularly in the dairy industry. The cluster project "Diversification in sheep $\&$ goat Sardinian dairy production" was built and carried out, based on requests from ten Sardinian dairy companies, to plan and implement experimental protocols directed to develop new production processes, according to the latest health and nutritional guidelines. Consequently, the following different interconnected research lines were developed: lactose-free dairy products; low-fat dairy products; dairy products enriched with added functional ingredients. The studied processes were based on the modification of cheese milk or whey, through the elimination of or reduction in one or more components with negative health effects or by adding functional ingredients. Therefore, a total of six different dairy products were developed: two from sheep milk and whey and four from goat milk. The technological processes adopted were typically those of Ricotta, fresh and soft cheeses. Contextually, their adaptability to the industrial equipment available in the cluster dairy companies was verified, and most of them were successfully transferred. These novel dairy products meet the current market demand, which shows a greater interest in fresh and short-ripened dairy products, with a low energy intake and high nutritional value. Moreover, can represent an example of the diversification in the sheep and goat dairy sector.
\end{abstract}

Keywords: lactose-free Ricotta; low-fat cheese; microparticulated whey proteins; functional ingredients

\section{Introduction}

In recent decades, consumer demand in the food sector has changed considerably. The current trends of the dairy market require companies to move towards more health-oriented production. This is also true for the sheep and goat dairy sector. Consumers have an increasing awareness about the strong relation between diet and human health. In this sense, functional foods play an important role and currently represent one of the major research areas in the food sector [1,2]. A commission of European experts in nutrition and medicine, composed by members of the Functional Food Science in Europe (FUFOSE) program, has defined "functional food". This is a food that can be satisfactorily demonstrated to beneficially affect one or more target functions in the body, beyond adequate nutritional effects, in a way that significantly improves health and wellbeing and/or reduces the risk of disease. Functional foods should be in the form of normal foods and they must demonstrate their effects in amounts that can normally be expected to be consumed in the diet. A functional food can be any food that naturally possesses components with demonstrable health properties: a food to which a component has been added, or a food from which a component has been removed by technological or biotechnological means. Additionally, it is possible to modify the nature of one or more of the food's 
components, or the bioavailability of one or more of its components, or even a combination of both. A functional food may be targeted at the whole population (e.g., probiotic drinks) or for particular groups of consumers (e.g., lactose-free products for lactose intolerant people) [3]. The only European legislative reference relating to nutrition and health claims made on food products is the Regulation (EC) No 1924/2006 and subsequent amendments. The same Regulations also list the "nutritional claims" allowed and the conditions for their application [4]. A list of authorized and non-authorized nutrition and health claims is constantly updated [5].

Dairy products occupy a significant space in the functional foods market and, among the milk-derived functional products, yoghurt and fermented milk are growing segments of this sector [6-8]. Functional milk products derive mainly from cow milk, while those made from goat and sheep milk are not as widespread in the market. Despite this, dairy products from small ruminants are currently considered of great interest for their intrinsic nutritional properties. The genetic polymorphism in goat and sheep milk proteins, beyond the quantitative aspect, also determines different qualitative aspects and, among other things, they can be responsible for the production of bioactive peptides. In goat milk, some genetic variants of proteins are known to make milk tolerable for patients suffering from an allergy to cow milk proteins. Feeding strategies in sheep and, in particular, the exploitation of natural pastures improve the nutritional properties of fat by raising polyunsaturated fatty acids, especially conjugated linoleic acids (CLA) [9].

The nutritional and health value of milk and related products can also be implemented by adding several functional ingredients, among which the most used are vitamins and minerals, antioxidant molecules, polyunsaturated fatty acids, proteins, protein fractions, amino acids, nucleotides, probiotic microorganisms (live microorganisms that confer health benefits to the host when administered in adequate amounts) and prebiotic substances (such as soluble fibers) [10].

This new idea of nutrition makes it necessary to identify "alternative" sheep and goat milk processing technologies aimed at improving the health and nutritional aspects, which could also satisfy the group of customers who are intolerant to some constituents of cow milk without losing the typical sensorial characteristics of the products. At the same time, technological innovation and diversification of sheep and goat dairy products could allow a competitive evolution and an improvement in the performance of the small ruminants dairy sector.

In Sardinia, which is the main producer of sheep and goat milk in Italy, the production lines and dairy plants are mainly suitable for the manufacturing of medium and long-aged cheeses. The most important cheese is Pecorino Romano, which represents about $50 \%$ of the sheep milk processed in Sardinia. A peculiar characteristic of this Protected Designation of Origin (PDO) cheese is its relevant presence in foreign markets and, in particular, in the United States and Canada, where about $60 \%$ of the total production is exported. Unfortunately, because of the Pecorino Romano cheese market, frequent and cyclical worsening of the profitability conditions of the sheep and goat sector often occurs. For this reason, it is important to think about a partial reconversion of the production lines, which must be increasingly oriented towards dairy products that are more appreciated by the modern consumer.

In this context fits the cluster project "Diversification in sheep \& goat Sardinian dairy production", which envisages the development of sheep and goat milk processing technologies that are "alternatives" to conventional ones. This cluster project was built and carried out based on requests from ten Sardinian dairy companies, which represent an important proportion (about 30\%) of the total sheep and goat milk processed in Sardinia. Among them, are the largest private and the largest cooperative dairy companies in Italy for sheep and goat milk processed per year. The aim of the project was to plan and implement experimental protocols directed to the development of new production processes, according to the latest health and nutritional guidelines.

Hence, new methodologies aimed at the realization of functional dairy products from sheep and goat milk were developed following different interconnected research lines which can be summarized as follows:

- lactose-free dairy products; 
- low-fat dairy products;

- dairy products enriched with added functional ingredients.

\section{Lactose-Free Dairy Products}

Dairy products are a source of lactose and therefore can cause various health problems if consumed by people suffering from intolerance towards this component. Lactose is a molecule formed by two monosaccharides (galactose and glucose) through a $\beta-1,4$ glycosidic bond. Normally, in humans, this bond is hydrolyzed by $\beta$-galactosidase. In lactose intolerant subjects, this enzyme decreases and, consequently, undigested lactose is metabolized from the gut microbiome, leading to unwanted symptoms like abdominal cramps, flatulence and diarrhea [11]. Worldwide, it is estimated that about $75 \%$ of the adult population shows a decline in lactase production at variable rates [12]. In Italy, the Ministry of Health, in a note on 7 July 2015, stated the conditions for claims about lactose content for "lactose-free" or "low-lactose" products. According to these indications, "lactose-free" can be used for milk and dairy products with a lactose residue less than $0.1 \mathrm{~g}$ per $100 \mathrm{~g}$ or $\mathrm{mL}$, while "low-lactose" is used if the residue is less than $0.5 \mathrm{~g}$ per $100 \mathrm{~g}$ or mL. However, the legislation still needs to be harmonized at the European level [13].

Since the demand for lactose-free dairy products is constantly increasing in the sheep and goat dairy sector, it was considered strategic by the cluster companies to develop such a functional food [12]. A reduction in the lactose content in dairy products is obtained through the controlled action of purified $\beta$-galactosidases [14].

The lactose hydrolysis technique generally consists of the addition of lactase directly to the milk destined for processing. Dairy companies usually develop processing lines dedicated to the manufacturing of lactose-free or low-lactose dairy products. A particular case is that of Ricotta cheese, for which this approach can be inadequate in relation to technical and commercial needs. The technological process to obtain Ricotta cheese involves the precipitation of the whey proteins by thermal denaturation, which, in the case of sheep cheese whey, usually takes place at $78-80^{\circ} \mathrm{C}[15,16]$. In addition, the largest part of Ricotta cheese is obtained from cheese whey from PDO cheese production which must be produced under PDO specifications.

In these cases, dairy companies could implement the production of lactose-free Ricotta cheese starting with the previous hydrolysis of the lactose contained in cheese whey. The latter is a byproduct of the dairy industry, containing mainly lactose, soluble proteins, minerals, and milk fat [16].

For this purpose, we developed, in collaboration with a dairy company involved in the cluster project, a technically and economically sustainable production process for lactose-free Ricotta cheese starting with sweet end-of-processing whey delactosed by adding a lactase enzyme.

The lactase enzyme is inactive at temperatures above $65^{\circ} \mathrm{C}$, so, the whey for lactose-free Ricotta cheese production must be previously subjected to lactose hydrolysis up to the pre-established residual value (less than $0.1 \mathrm{~g}$ of lactose per $100 \mathrm{~mL}$ of whey) before being processed [17,18]. This aspect excludes the possibility of using lactase in the same way as the manufacturing processes of lactose-free cheese or yoghurt, where the enzyme is added directly to the milk before its transformation, since the temperature does not exceed $65^{\circ} \mathrm{C}$ throughout these processes.

Lactase is marketed under various trade names characterized by a comparable enzymatic concentration. The enzyme GODO-YNL2 (DANISCO, Copenhagen, Denmark), obtained from the yeast Kluyveromyces marxianus ssp. lactis, was used in this study. According to the data provided by Danisco, the enzyme GODO-YNL2 has an optimal temperature range of $37-45^{\circ} \mathrm{C}$ and is able to hydrolyze, in $2 \mathrm{~h}, 75 \%$ of the lactose present in milk, and $100 \%$ in $6-8 \mathrm{~h}$ at $40^{\circ} \mathrm{C}$ and with a concentration of $0.20 \mathrm{~g} / \mathrm{L}$. These operating conditions, although advantageous from an economic point of view, would be practically inapplicable for the hydrolysis of lactose in cheese whey. Keeping the temperature at $40{ }^{\circ} \mathrm{C}$ such a long time is infeasible for cheesemaking, even if the milk is pasteurized to reduce the bacterial load. In these conditions, lactic fermentation produces the inevitable acidification of the whey, making it unsuitable for transformation into Ricotta cheese. Experimental trials were initially 
conducted at lab level to define the optimal conditions of lactase GODO-YNL2 hydrolysis in sheep cheese whey. The $\beta$-galactosidase activity was tested for doses, temperatures and hydrolysis times, in order to determine the best activity conditions for this enzyme in conjunction with the Ricotta cheese production process. Afterwards, the dose, temperature and time of hydrolysis were further adapted to the industrial process and to the needs of the company (Figure S1). The lactase dose was increased to $0.4 \mathrm{~g} / \mathrm{L}$ of whey. After pasteurization at $68^{\circ} \mathrm{C}$ for $30 \mathrm{~min}$, the whey was brought to a temperature of $40{ }^{\circ} \mathrm{C}$ and the lactase was added. The whey was then cooled down to $25^{\circ} \mathrm{C}$, kept at this temperature for $3 \mathrm{~h}$ and finally cooled down to $6-7^{\circ} \mathrm{C}$ and kept at this temperature for $15 \mathrm{~h}$ to complete lactose hydrolysis. The whey was then used for the production of lactose-free Ricotta cheese. Table 1 shows the physico-chemical parameters of the sweet sheep whey used and those of the lactose-free Ricotta cheese obtained. The content of lactose residue in the Ricotta cheese produced was $0.06 \pm 0.02 \mathrm{~g} / 100 \mathrm{~g}$, with a variability range between $0.01-0.09 \mathrm{~g} / 100 \mathrm{~g}$.

Table 1. Physico-chemical parameters of sweet sheep whey and lactose-free Ricotta cheese.

\begin{tabular}{lcc}
\hline Parameters & Sweet Sheep Whey & Lactose-Free Ricotta Cheese \\
\hline $\mathrm{pH}$ & 6.5 & 6.3 \\
Dry matter (\%) & 6.3 & 29 \\
Fat $(\%)$ & 0.7 & 14 \\
Fat/dry matter (\%) & - & 48 \\
Protein (\%) & 1.3 & 9.9 \\
Protein/dry matter (\%) & - & 34 \\
Lactose (\%) & 4 & 0.06 \\
\hline
\end{tabular}

In this way, it was possible to transfer the operating conditions for lactose hydrolysis previously tested in the laboratory to the company. The dairy industry subsequently developed a lactose-free Ricotta cheese production line, expanding the range of products marketed by the company and, at the same time, meeting the demand of a larger number of customers.

\section{Low-Fat Dairy Products}

The amount of energy or calories in a fixed weight of food, called energy density, is generally expressed as the number of calories per gram $(\mathrm{kcal} / \mathrm{g})$. Energy density values depend on the macronutrient composition of foods. Fat is the most energy dense component of food $(9 \mathrm{kcal} / \mathrm{g})$, while carbohydrates and protein provide less calories per gram $(4 \mathrm{kcal} / \mathrm{g})$. Foods with a high fat content have a relatively high energy density. Therefore, a reduction in fat intake can reduce the energy density of the diet [19]. For this reason, a decrease in the fat content of dairy foods is one of the most applied strategies by dairy companies to reduce the energy value of their products. Italian law, No. 142 of 19 February 1992, establishes that cheeses can be defined as "low-fat" if the fat content in relation to the dry matter is less than $20 \%$ or "light" if it is between $20 \%$ and $35 \%$ [20]. According to Regulation (EC) No. 1924/2006, a cheese may be labelled as reduced fat if the reduction in fat content is at least $30 \%$ compared to a similar product [4].

From a technological point of view, lowering the fat content in cheeses takes place by reducing the fat/protein ratio in milk. This is generally done by removing a predetermined amount of fat from the milk or, more rarely, by increasing the protein content. Fat removal from milk destined to cheesemaking has a depressing effect on cheese yield as well as some negative effects on the rheological and sensorial characteristics of the resulting cheese [21]. Fat globules are scattered in the cheese matrix within the casein network. Therefore, they loosen the interaction forces and act like a lubricant, giving a more viscous and less consistent structure to the cheese [22]. For this reason, low-fat cheeses generally have a more cohesive, elastic and consequently more rubbery structure than corresponding full-fat cheeses. Several low-fat cheese processes have been developed with the aim of minimizing the negative effects of fat reduction on cheese yield and on the rheological and sensorial characteristics of the final product. 
The use of ingredients that mimic several of the physiochemical desirable properties of fat could be an interesting approach. These substances, named fat replacers, have a water-binding property that gives a sense of lubricity and creaminess to the foods [21,23].

In this context, we developed a technological approach to produce dairy products from sheep and goat milk with reduced fat content by partially replacing the natural fat of milk with some fat replacers. Microparticulated whey proteins (MWP) and inulin, a natural dietary fiber, were used for this purpose. Ultrafiltration technology was also a useful technique used to standardize the protein content in order to obtain dairy products with a predefined composition and reduced energy value.

\subsection{Microparticulated Whey Proteins as Fat Replacer}

The addition of MWP to cheese milk, via rennet or acid-rennet coagulation, represents a challenge for dairy technology. MWP seem to be one of the most interesting fat replacers in cheesemaking processes. It is obtained from cheese whey, which is a byproduct of cheesemaking derived from milk coagulated by rennet, concentrated by ultrafiltration, thermally denatured under constant stirring and subsequently subjected to microparticulation by means of a mechanical treatment such as homogenization. This treatment reduces the size of denatured whey protein macro-aggregates until they are reduced into particles whose size simulates those of milk fat globules $(1-10 \mu \mathrm{m})$, as shown in Figure 1 [24].

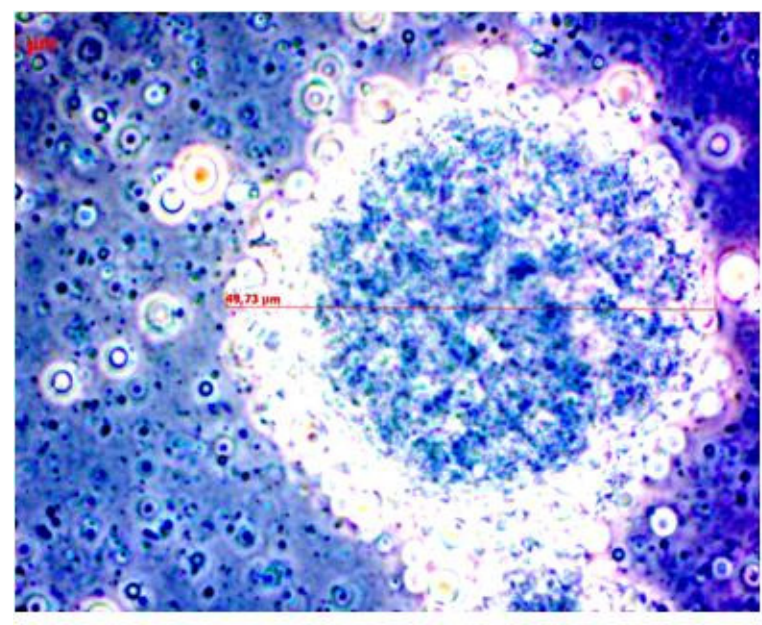

(a)

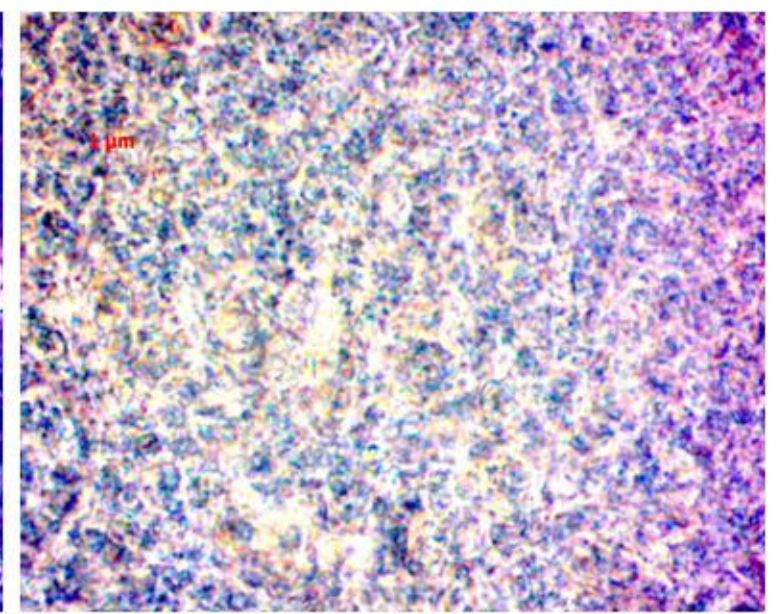

(b)

Figure 1. Heat-denatured whey proteins aggregates before (a) and after microparticulation (b), (1000x magnification).

The functional properties of the thermal denatured whey proteins, associated with the microparticulation, give MWP features similar to those of milk fat, making it suitable for use as a fat replacer in low-fat dairy products. Several studies show that MWP are able to improve the sensory properties of low-fat products, giving them the same palatability and consistency as full fat ones [24-27]. Furthermore, the addition of MWP to cheese milk is very interesting from a nutritional point of view not only for its reduced energy density, but also for the high biological value added by whey proteins [28]. MWP produced from cow rennet whey (Simplesse ${ }^{\circledR}$, CP Kelco Germany GmbH, Großenbrode, Germany; Dairy-Lo ${ }^{\circledR}$, Pfizer, New York, NY, USA; etc.) are available on the market, while those obtained from sheep and goat whey are not.

The use of goat MWP was tested within the framework of this project to produce a short-ripened goat milk cheese obtained by rennet coagulation (Figure S2). MWP were produced from a commercial goat whey protein concentrate (WPC, 50\% protein, AVH dairy trade B.V., Heerhugowaard, The Netherlands). WPC was diluted to $10 \%$ protein content, adjusted to $\mathrm{pH}$ 6.60 and subjected to a denaturation heat treatment $\left(80^{\circ} \mathrm{C} \times 10 \mathrm{~min}\right)$ to precipitate the whey proteins as macro-aggregates. The precipitate was then submitted to vigorous stirring, using a high-speed 
disperser (ULTRA-TURRAX ${ }^{\circledR}$ T25, IKA, Staufen, Germany) and subsequently microparticulated by a high-pressure homogenizer (Panther NS3006L, GEA Niro Soavi, Parma, Italy). This method allows dairy companies without an ultrafiltration plant to produce MWP from whey powders (WPC), which are easily available on the market. The obtained goat MWP was added to the goat cheese milk to increase the protein content by 10\%, 20\% and 30\% compared to its natural value (Table 2). Control and protein-fortified milk were then thermized and processed.

Table 2. Physico-chemical parameters and cheese yield of the experimental goat milk cheesemaking process with the addition of microparticulated whey proteins (MWP) in different amounts (4\%, $8 \%$ and $12 \%$ ) to cheese milk.

\begin{tabular}{|c|c|c|c|c|c|c|c|c|c|}
\hline \multirow{2}{*}{ Parameters } & \multicolumn{5}{|c|}{ Starting Cheese Milk } & \multicolumn{4}{|c|}{ Cheese (C) After 15 Days } \\
\hline & MWP & Milk Control & $4 \%$ MWP & $8 \%$ MWP & $12 \%$ MWP & C Control & C $4 \%$ MWP & C 8\% MWP & C 12\% MWP \\
\hline $\mathrm{pH}(\mathrm{UpH})$ & 6.60 & 6.68 & 6.64 & 6.66 & 6.67 & 5.62 & 5.15 & 5.21 & 5.14 \\
\hline Dry matter (\%) & 17.68 & 10.83 & 11.20 & 11.52 & 11.80 & 43.27 & 37.85 & 37.94 & 36.74 \\
\hline Fat $(\%)$ & 3.40 & 3.04 & 3.10 & 3.14 & 3.17 & 20.72 & 16.11 & 16.27 & 15.19 \\
\hline Fat/dry matter (\%) & - & - & - & - & - & 47.88 & 42.57 & 42.88 & 41.34 \\
\hline Protein $(\%)$ & 9.93 & 3.04 & 3.31 & 3.59 & 3.92 & 17.31 & 15.80 & 17.73 & 17.16 \\
\hline Fat/protein & 0.34 & 1.00 & 0.91 & 0.85 & 0.80 & - & - & - & - \\
\hline Casein/whey proteins & 0.56 & 2.35 & 1.99 & 1.68 & 1.46 & - & - & - & - \\
\hline Lactose $(\%)$ & 3.60 & 4.09 & 4.14 & 4.12 & 4.12 & - & - & - & - \\
\hline Energy value (kcal/100 g) & - & - & - & - & - & 263.7 & 216.2 & 225.4 & 213.4 \\
\hline A. cheese yield ${ }^{1}(\%)$ & - & - & - & - & - & 13.0 & 16.9 & 17.3 & 18.6 \\
\hline M.A. cheese yield ${ }^{2}(\%)$ & - & _- & - & _- & _- & 13.0 & 15.6 & 15.6 & 16.2 \\
\hline
\end{tabular}

${ }^{1}$ Actual cheese yield at $24 \mathrm{~h}(\mathrm{~kg} / 100 \mathrm{~kg}$ of milk $\times 100) ;{ }^{2}$ M.A. (moisture-adjusted) cheese yield (actual yield adjusted to the moisture content of the control cheese at $24 \mathrm{~h}$ ).

The addition of MWP to the milk involved a change in the technological properties of the cheese milk. This aspect was mainly due to both a quantitative and qualitative modification of the protein fraction (decrease in casein/whey proteins ratio) and to the direct interference of the microparticulated proteins with the curd formation. These effects are dose dependent and, in particular, cause a delay in rennet coagulation time, a reduction in curd cohesion and firmness, and are particularly evident in milk with the highest level of MWP integration. As shown in Table 2, the experimental cheeses obtained with the addition of MWP had a higher moisture content and a lower fat percentage in dry matter, with a softer and less cohesive texture than the control cheese. As a result of the fat content reduction, experimental cheeses were characterized by an energy value which was 15-20\% lower than the control cheese. Actual cheese yield, calculated at $24 \mathrm{~h}(\mathrm{~kg} / 100 \mathrm{~kg}$ of milk), and moisture-adjusted cheese yield (actual cheese yield adjusted to the moisture content of the $24 \mathrm{~h}$ control cheese) were both higher in experimental cheeses with respect to the control cheese, suggesting that the cheese yield increase was not only related to the increased moisture content, but probably also to MWP captured in the curd and finally in the cheese. MWP in cheese seem to act as inert fillers that weaken the casein network, causing a lower gel contraction that, together with the water-binding capacity of the added whey proteins, results in a relevant increase in moisture. Moreover, the lowering of the gel firmness upon cutting also causes less efficiency in the fat recovery because of the higher fat losses via curd fines in whey. This is the reason why cheeses produced with the addition of MWP were less fatty. Similar findings are reported by several authors for cow milk $[24-27,29,30]$.

The adaptability of the MWP production technique was also verified by a dairy company involved in the cluster project by using an ultrafiltration system available in their cheese plant. In this case, whey derived from sheep cheese milk was concentrated by ultrafiltration, heat denatured and homogenized to obtain MWP, which were then used to produce a soft cheese from sheep milk (Figure S3). In the experimental cheesemaking, MWP were added to cheese milk at an amount of about $5 \%$ during the filling phase of the coagulation vat. This amount allowed us to obtain a modest delay in clotting time that was corrected by a slight increase in the rennet dosage. The experimental cheese showed, at the end of ripening, a higher moisture content, a lower fat content in its dry matter, a lower energy value and a higher cheese yield than the control cheese (Table 3). In this case, as shown by the moisture-adjusted cheese yield, the actual increment in the cheese yield of the experimental cheese was due to the increase in the moisture content. This increase was probably linked to the water-binding 
capacity of the MWP retained inside the curd, together with a weakening of the casein network contraction due to the added whey proteins. These results confirm a change in the technological aptitude of the cheese milk.

Table 3. Physico-chemical parameters and cheese yield of the experimental sheep milk cheesemaking process with the addition of about $5 \%$ microparticulated whey proteins (MWP) to cheese milk.

\begin{tabular}{|c|c|c|c|c|c|}
\hline \multirow{2}{*}{ Parameters } & \multicolumn{3}{|c|}{ Starting Cheese Milk } & \multicolumn{2}{|c|}{ Cheese After 15 Days } \\
\hline & MWP & Milk (Control) & 5\% MWP & Control Cheese & Experimental Cheese \\
\hline $\mathrm{pH}(\mathrm{UpH})$ & 6.65 & 6.58 & 6.56 & 5.13 & 4.98 \\
\hline Dry matter (\%) & 21.20 & 15.30 & 16.30 & 55.8 & 52.9 \\
\hline Fat $(\%)$ & 6.76 & 5.26 & 5.53 & 28.50 & 25.70 \\
\hline Fat/dry matter (\%) & - & - & - & 51.10 & 48.60 \\
\hline Protein $(\%)$ & 9.36 & 5.14 & 5.43 & 22.40 & 21.60 \\
\hline Fat/protein & 0.72 & 1.02 & 1.02 & - & - \\
\hline Casein/whey proteins & - & 4.27 & 2.78 & - & - \\
\hline Lactose $(\%)$ & 4.24 & 4.42 & 4.58 & - & - \\
\hline Energy value (kcal/100 g) & - & - & - & 354.1 & 325.7 \\
\hline A. cheese yield ${ }^{1}(\%)$ & - & - & - & 18.9 & 20.7 \\
\hline M.A. cheese yield ${ }^{2}(\%)$ & - & - & - & 18.9 & 19.1 \\
\hline
\end{tabular}

Therefore, through this study, two different ways to produce MWP were developed in dairy companies, either from whey powder or directly from sweet cheese whey. However, we think that the major goal was to solve the critical issues in the technological transfer to dairy companies and the need to adapt facilities and equipment, consequently leading to necessary investments. This aspect is particularly relevant for the sheep and goat dairy sector, which is still closely linked to conventional processing technologies.

\subsection{Ultrafiltration Technology in the Manufacturing of Low-Fat Dairy Products}

As an alternative to the use of fat replacers, we developed a technological process for the manufacturing of fresh cheese from goat milk with a predetermined gross composition and reduced fat content, through the application of the ultrafiltration technique [31]. This membrane filtration process allows the concentration of the macro components that are useful for cheesemaking, by eliminating most of the water and soluble compounds.

The traditional manufacturing processes for fresh cheese production generally involve the acid coagulation of cheese milk and whey expulsion from the curd by using various separation techniques. Whey drainage from curd is difficult to control and often causes variability in the composition and quality of the final product, as well as inevitable losses in macronutrients. In addition, the traditional cheesemaking processes do not require the standardization of the natural components of the milk. Consequently, the composition of dairy products is affected by the seasonal variation in the whole milk. The ultrafiltration technique is a useful technology in the manufacturing of reduced-fat products and can standardize their composition. Once concentrated and denatured, whey proteins have the ability to form compact aggregates that are incorporated in the casein network and have a great water-binding capacity [32]. This property, used both to increase cheese yield and to improve the textural characteristics in soft and fresh cheeses, becomes particularly interesting in the production of low-fat cheeses, to compensate for the negative effect on the structure determined by the reduction in fat content.

The ultrafiltration technique is also important to produce dairy products with a predefined composition, starting from milk whose natural components (fat and protein in particular) are standardized by an addition and/or reduction in these components, according to the expected composition of the final product. This approach eliminates the seasonal variability in the content of natural milk components, which is particularly evident in sheep and goat milk, and makes it possible 
to obtain a product with defined and constant physical-chemical, nutritional and sensory features over time, all of which are fundamental requirements for a quality product.

With this in mind, we developed a fresh goat milk cheese made with different milk formulations obtained by mixing predetermined amounts of whole goat milk, skim goat milk concentrated by ultrafiltration (retentate) and goat milk cream (Figure S4). The ultrafiltration of the skim milk was carried out by using a pilot plant (Mete S.r.l., Membrane Technology, Varese, Italy) equipped with a spiral-wound membrane in polyethersulfone (PES) (cut-off: $20 \mathrm{kDa}$; nominal area: $5 \mathrm{~m}^{2}$; Celgard, Charlotte, NC, USA). The transmembrane pressure, process temperature and recirculation flow rate were $0.17 \mathrm{MPa}, 25^{\circ} \mathrm{C}$ and $2.6 \mathrm{~m}^{3} / \mathrm{h}$, respectively. The pre-established volumetric concentration ratio (VCR) was set to four and corresponded to $13 \%$ protein content in the retentate. Three formulations with different fat to dry matter ratios $(40 \%, 30 \%$ and $20 \%)$ were prepared. Proportionally, the protein content was increased to compensate for the lower fat content, and the same level of total solids in cheese was kept (about 22\%). The characteristics of starting components and final products are reported in Table 4 . The exact amount of the single components (whole milk, retentate and cream) used for the milk formulations was determined by applying a system of equations that takes into account the fat and protein concentration in the three mixtures and in the ingredients. From the resolution of this system of equations, the mathematical formulae shown in Figure 2 were obtained.

Table 4. Physico-chemical parameters of starting components and fresh cheeses with a predetermined chemical composition and different fat contents at $48 \mathrm{~h}$ after production, obtained from goat milk.

\begin{tabular}{|c|c|c|c|c|c|c|c|}
\hline Parameters & \multicolumn{4}{|c|}{ Starting Components } & \multicolumn{3}{|c|}{ Cheese } \\
\hline $\mathrm{pH}(\mathrm{UpH})$ & 6.67 & 6.51 & 6.60 & 6.55 & 4.83 & 4.64 & 4.59 \\
\hline Fat $(\%)$ & 3.41 & 68.1 & 0.05 & 0.30 & 4.43 & 6.60 & 8.73 \\
\hline Fat/Dry matter (\%) & - & - & - & - & 19.7 & 29.8 & 40.2 \\
\hline Whey proteins (\%) & 0.46 & - & 0.47 & 1.88 & 1.34 & 1.11 & 0.84 \\
\hline Lactose $(\%)$ & 4.28 & - & 4.55 & 4.60 & 2.18 & 2.38 & 2.70 \\
\hline Energy value (kcal/100 g) & - & - & - & - & 97.3 & 111.7 & 123.7 \\
\hline
\end{tabular}

${ }^{1}$ Cheese with $20 \%$ fat to dry matter ratio; ${ }^{2}$ cheese with $30 \%$ fat to dry matter ratio; ${ }^{3}$ cheese with $40 \%$ fat to dry matter ratio.

$$
x=\frac{\left[a_{1} \cdot\left(b_{4}-b_{3}\right)+a_{3} \cdot\left(b_{1}-b_{4}\right)+a_{4} \cdot\left(b_{3}-b_{1}\right)\right] \cdot m}{a_{2} \cdot\left(b_{4}-b_{3}\right)+a_{3} \cdot\left(b_{2}-b_{4}\right)+a_{4} \cdot\left(b_{3}-b_{2}\right)}
$$

$y=-\frac{\left[a_{1} \cdot\left(b_{4}-b_{2}\right)+a_{2} \cdot\left(b_{1}-b_{4}\right)+a_{4} \cdot\left(b_{2}-b_{1}\right)\right] \cdot m}{a_{2} \cdot\left(b_{4}-b_{3}\right)+a_{3} \cdot\left(b_{2}-b_{4}\right)+a_{4} \cdot\left(b_{3}-b_{2}\right)}$

$$
z=\frac{\left[a_{1} \cdot\left(b_{3}-b_{2}\right)+a_{2} \cdot\left(b_{1}-b_{3}\right)+a_{3} \cdot\left(b_{2}-b_{1}\right)\right] \cdot m}{a_{2} \cdot\left(b_{4}-b_{3}\right)+a_{3} \cdot\left(b_{2}-b_{4}\right)+a_{4} \cdot\left(b_{3}-b_{2}\right)}
$$

$$
\begin{aligned}
& x=\text { Whole milk }(\mathrm{kg}) \\
& y=\text { Retentate }(\mathrm{kg}) \\
& z=\text { Cream }(\mathrm{kg}) \\
& m=\text { Mixture }(\mathrm{kg}) \\
& a_{1}=\text { Fat in mixture }(\mathrm{kg}) \\
& a_{2}=\text { Fat in whole milk }(\%) \\
& a_{3}=\text { Fat in retentate }(\%) \\
& a_{4}=\text { Fat in cream }(\%) \\
& b_{1}=\text { Protein in mixture }(\mathrm{kg}) \\
& b_{2}=\text { Protein in whole milk }(\%) \\
& b_{3}=\text { Protein in retentate }(\%) \\
& b_{4}=\text { Protein in cream }(\%)
\end{aligned}
$$

Figure 2. Mathematical formulae to calculate milk mixture components.

The acid-rennet coagulation of milk occurred directly in the final package, without any whey drainage. Therefore, cheeses presented the same chemical composition of the initial milk formulations. 
This process allows the total recovery of the useful matter available in the starting milk formulation, guaranteeing a high cheese yield. The experimental cheeses had a low energy intake, even in the formulation with the highest fat content $(124 \mathrm{kcal} / 100 \mathrm{~g})$ (Table 4). This level is lower with respect to that found in commercial products, which generally varies from $179 \mathrm{kcal} / 100 \mathrm{~g}$ in the light version to $313 \mathrm{kcal} / 100 \mathrm{~g}$ in the full-fat version [33]. Moreover, the experimental cheeses had a potentially higher nutritional value due to their greater mineral availability and the increased biological value of their protein fraction. In relation to sensory aspects, the experimental cheeses showed a good level of acceptability, proving that the studied process can reduce negative effects due to the fat content reduction. Furthermore, this cheesemaking process could be suitable to produce a dairy cheese matrix that is able to incorporate several functional ingredients to obtain a wide variety of functional products.

\subsection{Inulin as Fat Replacer}

Many carbohydrates can be used for total or partial fat replacement in food [34]. Digestible carbohydrates provide, on average, $4 \mathrm{kcal} / \mathrm{g}$, while complex non-digestible carbohydrates, like fiber, have a relatively low energy density $(1.5-2.5 \mathrm{kcal} / \mathrm{g})$ [19]. Carbohydrate-derived fat replacers generally exert their replacement action by stabilizing the water in a gel-like matrix. In this way, they increase the viscosity and the creaminess on the palate, similarly to full-fat products [34]. Among the dietary fibers that can be used as fat replacers, our interest was addressed to inulin. This is a natural food ingredient found extensively in various species of plants (chicory root is considered the richest source) and, together with oligofructose, belongs to a group of carbohydrates called fructans. Chemically, inulin is a water-soluble storage polymer consisting of fructose units linked together with $\beta-2,1$ bonds ending with a glucose residue. In nature, we find molecules with a different length that can vary from two to 250 units of fructose. The degree of polymerization (DP) allows us to differentiate oligofructose, a subgroup of inulin with an average DP less than 10, from long-chain inulin with an average DP of about 23 . Bond $\beta$-configuration makes inulin non-digestible, unlike a typical carbohydrate. However, it can be fermented in the large intestine by the gut microbiota. Inulin, compared to simple carbohydrates, being partially digestible, is characterized by a reduced caloric value (about $1.5 \mathrm{kcal} / \mathrm{g}$ ). This characteristic, together with its ability to increase the feeling of satiety, makes inulin an excellent ingredient for the development of dietetic food products. As a fiber, inulin allows improved feces consistency and frequency. It also acts as a prebiotic, promoting the growth and metabolic activity of a limited number of health beneficial bacteria in the colon, called probiotics, such as Bifidobacteria and Lactobacilli. In particular, the concomitant increase in the number of probiotic microorganisms and products resulting from the fermentation of inulin at an intestinal level can lead to a variety of beneficial physiological effects. Among the fermentation products, short-chain fatty acids (acetic acid, propionic acid and butyric acid) can reduce the $\mathrm{pH}$ and prevent the growth of pathogenic bacteria like Salmonella, Escherichia coli and Clostridium [35,36].

From the technological point of view, long-chain inulin is capable of forming gels whose properties make them perfect fat replacers that are suitable for the partial or total replacement of fat in dairy products such as yoghurt, fermented milk and fresh cheese. These types of gels can improve palatability and creaminess in low-fat dairy products [37]. However, a technological drawback exists because inulin is a soluble fiber and, consequently, it is partly lost in the whey during traditional cheesemaking processes. Therefore, we developed a technological approach to overcome this problem, using long-chain inulin to replace fat in the manufacturing of fresh goat milk cheese (Figure S5) [38]. With this purpose, cheese milk was standardized to keep a constant protein and dry matter content in the final product. The ultrafiltration technique was used to concentrate skim goat milk, to obtain a retentate with $9 \%$ protein content. The retentate was then mixed in different amounts with milk cream and inulin $\mathrm{DP} \geq 23$ (Frutafit TEX, Sensus, The Netherlands) to make fresh cheese with a predetermined chemical composition and without any syneresis or draining of whey during the acidification, coagulation and storage. Four mixtures were prepared, keeping the total solids content constant $(22 \%)$ and replacing 
fat with a proportional increase in inulin content from $2 \%$ to $7 \%$, while maintaining the protein content constant. The physico-chemical characteristics of the obtained cheeses are reported in Table 5.

Table 5. Physico-chemical parameters of fresh goat milk cheeses with a predetermined chemical composition and different inulin contents at $48 \mathrm{~h}$ after production.

\begin{tabular}{|c|c|c|c|c|}
\hline Parameters & IN0 $^{1}$ & IN2 $^{2}$ & IN5 $^{3}$ & IN7 $^{4}$ \\
\hline $\mathrm{pH}(\mathrm{UpH})$ & 4.49 & 4.51 & 4.49 & 4.50 \\
\hline Dry matter (\%) & 21.51 & 21.81 & 21.73 & 21.69 \\
\hline Fat $(\%)$ & 8.88 & 6.99 & 4.16 & 2.13 \\
\hline Protein $(\%)$ & 8.13 & 8.09 & 8.02 & 8.03 \\
\hline Inulin $(\%)$ & 0.00 & 2.00 & 5.00 & 7.00 \\
\hline Energy value (kcal/100 g) & 120.44 & 107.07 & 86.96 & 72.59 \\
\hline
\end{tabular}

Inulin as a fat replacer has proved to be particularly valid to obtain fresh cheese from goat milk, with potentially functional characteristics (rich in prebiotics and low in fat) through the applied technological process. The acidification, coagulation and storage of this cheese occur directly in the final packaging, with a total absence of syneresis during the storage and for the whole shelf-life. This ensures the optimal use of inulin, which would otherwise be lost during whey separation, which happens in cheesemaking. Moreover, flavor and taste in the final product did not differ from the control cheese (full fat), and these aspects, combined with the higher creaminess found in inulin-fortified cheeses, could make the product attractive to consumers.

\section{Dairy Products Enriched with Added Functional Ingredients}

Food fortification or enrichment refers to the addition of micronutrients to food without changing its energy value. According to the definition given by the World Health Organization (WHO) and the Food and Agricultural Organization of the United Nations (FAO), fortification is defined as "the practice of deliberately increasing the content of an essential micronutrient, i.e., vitamins and minerals (including trace elements) in food, to improve the nutritional quality of the food supply and provide a public health benefit with minimal risk to health", while enrichment "is synonymous with fortification and refers to the addition of micronutrients to a food irrespective of whether the nutrients were originally in the food before processing or not" [39].

As for the development of new dairy products from sheep and goat milk, enriched with nutritional and functional elements, on the bases of requests from several dairy companies, we considered the following approaches:

- increases in whey protein content;

- increases in omega-3 fatty acid content;

- use of prebiotics (inulin) and probiotic microorganisms.

Whey proteins represent approximately $15-20 \%$ of the total milk proteins and consist mainly of $\beta$-lactoglobulin (about 50\%), $\alpha$-lactalbumin (about 15-20\%), immunoglobulins (about 10\%), and serum albumin (about 10\%) [16,40]. Whey proteins are an important functional ingredient with proven positive effects on human health. Many studies show that bioactive peptides derive from whey proteins and the same ones can have different biological activities, including antimicrobial, antiviral, anticancer, antioxidant, anti-inflammatory, immunomodulatory and antidiabetic activities [41,42]. Methods to increase the whey protein content were discussed extensively in the previous section about both the use of MWP and the ultrafiltration technique.

As for the increase in omega-3 fatty acid content, this was obtained by adding an algal oil, as a source of polyunsaturated fatty acids of the omega-3 series (PUFA- $w 3$ ), consisting mainly of eicosapentaenoic acid (EPA C20:5) and docosahexaenoic acid (DHA C22:6). We used oil derived from 
the marine alga Schizochytrium sp. and its EPA and DHA content was 150 and $300 \mathrm{mg} / \mathrm{g}$, respectively. Algal oil is often used, both in infant formulae and as a dietary supplement. Different investigations show, in fact, that DHA and EPA are important in the development of the central nervous system and, in recent years, have received great interest because they have proved to be effective in reducing the risk of cardiovascular disease and in preventing some types of cancer [43,44]. There are several recommendations regarding the daily intake of DHA and EPA in the diet, according to different categories of people, given by government agencies and international organizations that oversee the health of the world population. For example, FAO recommends $250 \mathrm{mg} /$ day as the minimum daily intake of EPA + DHA for a healthy diet aimed at the prevention of cardiovascular disease [45]. However, the dietary intake of omega- 3 fatty acids, in industrialized countries is considerably lower than recommended intake levels [46]. The fortification of foods with omega-3 rich oils from marine sources (fish or microalgae) is, therefore, one of the possible strategies to increase the daily intake of these essential fatty acids. However, this oil addition may lead to the development of an unpleasant taste and odor in the fortified products, especially in combination with the high susceptibility to oxidative deterioration of fish and algal oil that accelerates the formation of an off-flavor. Dairy products, such as yoghurt and fermented milk, are good candidates for omega-3 fortification, not only because of the high frequency of their consumption, but also because of their ideal storage conditions $[47,48]$.

Regarding prebiotic ingredients, the use of the soluble fiber inulin has previously been discussed in detail. As a prebiotic, inulin is able to modify the gut microbiota and to stimulate the growth and activity of some beneficial bacterial species, known as probiotics, in the intestine. According to FAO/WHO guidelines, probiotic bacteria are defined as "live microorganisms that, when administered in adequate amounts, confer a health benefit on the host" [49]. The synergistic effect between prebiotic and probiotic bacteria is defined as symbiotic: prebiotics enhance the survival of probiotics and their ability to colonize the intestinal tract. Different clinical health benefits, on the basis of the currently available literature, are attributed to probiotic bacteria. They can compete with various enteric pathogens for adhesion to the gut, acting as an intestinal barrier. Immunomodulatory, anti-inflammatory, anticancer, anti-obesity and antidiabetic activities are also properties ascribed to probiotics [50,51]. Currently, however, the European Food Safety Authority (EFSA) has approved no nutrition and health claims for probiotics. The single evidence of intestinal colonization of a probiotic, as proof of a useful action for the balance of the intestinal flora, is not enough to sustain a beneficial effect on human health. In Italy, the Ministry of Health has maintained the use of "probiotics" for food and food supplements under specific conditions, including a minimum level of $1 \times 10^{9}$ colony-forming units (CFU) administered daily, a complete genetic characterization of the probiotic strain, and a proven tradition of safe use in the Italian market [52]. The most commonly used probiotic bacteria in foods are lactic acid bacteria belonging to the genera Lactobacillus and Bifidobacterium.

Therefore, taking into account these nutritional aspects, we have developed a functional product obtained by the acid coagulation of goat milk enriched in nutrients with a functional value, together with the addition of the probiotic bacterial culture Bifidobacterium animalis subsp. lactis, (BB-12 ${ }^{\circledR}, \mathrm{Chr}-\mathrm{Hansen}$, Hoersholm, Denmark) (Figure S6) [53]. In this study, the technological process involved the use of enriched milk, prepared by mixing predetermined amounts of whole goat milk, skim goat milk and/or goat milk cream, MWP made from a commercial whey goat milk concentrate (WPC, 50\% protein, AVH dairy trade B.V., The Netherlands) as a source of whey protein, marine algal oil as a source of the omega-3 fatty acids DHA and EPA (Life's omega 45, DSM, Denmark), and inulin DP $\geq 20$ as a fiber source (Fibruline XL, Cosucra, Belgium). The amounts of the single components (whole milk, skim milk, cream, MWP, algal oil and inulin) used for the milk formulation were determined by applying a system of equations, taking into account the composition of the final formulation and the ingredients. The equation system was similar to that shown in Figure 2. The enriched milk was homogenized, pasteurized, and inoculated with starter and aroma cultures together with the probiotic culture BB- $12^{\circledR}$. The final product, as a result of the applied technology, showed a chemical composition comparable to the enriched milk at the start because the process presented a low evaporation and no 
whey separation (Table 6). The fat content was $4 \%$ (75\% from goat milk and $25 \%$ from algal oil); the protein content was $5 \%$ ( $50 \%$ casein and $50 \%$ whey proteins); the inulin content was $7 \%$; the DHA and EPA contents were, respectively, $0.3 \%$ and $0.16 \%(300 \mathrm{mg} / 100 \mathrm{~g}$ and $160 \mathrm{mg} / 100 \mathrm{~g})$; the energy value was $85 \mathrm{kcal} / 100 \mathrm{~g}$. The functional product had specific nutritional properties derived from the increased whey protein content $(170 \%$ more than the normal goat milk), the high content of omega- 3 fatty acids and the soluble prebiotic fiber inulin, combined with the probiotic culture. In addition, the product had a limited energy value and the protein content (especially whey proteins) associated together with the fiber gave the product good satiating properties. The physico-chemical and nutritional features of the formulation were stable during storage at $4{ }^{\circ} \mathrm{C}$ for 30 days, with a probiotic bacteria count just over $8 \log _{10} \mathrm{CFU} / \mathrm{g}$. The product had a smooth and fluid consistency, comparable to a yoghurt drink, and was judged to be pleasant, creamy, and not excessively acidic. Furthermore, the content of marine algal oil did not seem to cause an off-flavor.

Table 6. Physico-chemical characteristics of starting components, enriched goat milk (EM) and functional product (FP), with a predetermined chemical composition at $24 \mathrm{~h}$.

\begin{tabular}{|c|c|c|c|c|c|c|c|c|}
\hline \multirow{2}{*}{ Parameters } & \multicolumn{6}{|c|}{ Starting Components } & \multirow[b]{2}{*}{$\mathrm{EM}^{2}$} & \multirow[b]{2}{*}{ FP $^{3}$} \\
\hline & Goat Milk & Skim Milk & Cream Milk & MWP $^{1}$ & Algal oil & Inulin & & \\
\hline $\mathrm{pH}(\mathrm{UpH})$ & 6.68 & 6.60 & 6.56 & 6.60 & - & 7.00 & 6.70 & 4.51 \\
\hline Dry matter (\%) & - & - & - & - & - & - & 20.64 & 20.01 \\
\hline Fat $(\%)$ & 3.79 & 0.16 & 58.38 & 3.37 & 99.98 & - & 4.01 & 4.10 \\
\hline Protein (\%) & 3.26 & 3.30 & 2.05 & 9.90 & - & - & 4.96 & 5.00 \\
\hline Casein $(\%)$ & 2.34 & 2.43 & - & 3.54 & - & - & 2.52 & 2.54 \\
\hline Whey proteins (\%) & 0.92 & 0.84 & - & 6.30 & - & - & 2.48 & 2.50 \\
\hline Casein/whey proteins & 2.56 & 2.90 & - & 0.56 & - & - & 1.02 & 1.02 \\
\hline Lactose $(\%)$ & 4.07 & 4.22 & - & 3.83 & - & - & 3.59 & 2.19 \\
\hline Inulin (\%) & - & - & - & - & - & 95.00 & 7.00 & 7.00 \\
\hline $\mathrm{DHA}^{4}(\%)$ & - & - & - & - & 30.00 & - & 0.29 & 0.30 \\
\hline $\mathrm{EPA}^{5}(\%)$ & - & - & - & - & 15.00 & - & 0.15 & 0.16 \\
\hline Energy value (kcal/100 g) & - & - & - & - & - & - & - & 84.57 \\
\hline
\end{tabular}

This functional product met the nutritional requirements of three nutrition claims listed in Regulation (EC) No 1924/2006 and in the subsequent amendment, Regulation (EU) No 116/2010:

- "High protein", since $23 \%$ of its energy value was provided by proteins, compared to the minimum value of $20 \%$ established by the Regulation [4].

- "High fiber", since it contained about $7 \mathrm{~g}$ of soluble fiber (inulin) per $100 \mathrm{~g}$ and per $85 \mathrm{kcal}$, compared with the minimum level of $6 \mathrm{~g}$ of fiber per $100 \mathrm{~g}$ or $3 \mathrm{~g}$ of fiber per $100 \mathrm{kcal}$, as fixed by the Regulation [4].

- "High omega-3 fatty acids", since it contained $460 \mathrm{mg}$ of the sum of DHA and EPA per $100 \mathrm{~g}$ and per $85 \mathrm{kcal}$, compared to the minimum value of $80 \mathrm{mg}$ (DHA + EPA) per $100 \mathrm{~g}$ and per $100 \mathrm{kcal}$ specified by the Regulation [54].

Moreover, $100 \mathrm{~g}$ of the functional product would provide a daily intake that meets the Italian Ministry of Health's guidelines for probiotics [52]. These guidelines recommend $9 \log _{10}$ of viable cells per day, an amount available in $100 \mathrm{~g}$ of a product with a probiotic bacteria count of $7 \log _{10} \mathrm{CFU} / \mathrm{g}$. The functional product of this study fully satisfied this condition because the concentration of viable probiotic cells exceeded the value of $1 \log _{10} \mathrm{CFU} / \mathrm{g}$.

\section{Conclusions}

The outcomes of the research conducted within the framework of the project "Diversification in sheep \& goat Sardinian dairy production" together with several Sardinian dairy companies have enabled the development of technological processes for manufacturing dairy products made from sheep and goat milk, with high nutritional and functional properties. The studied processes were based 
on the modification of milk destined for cheesemaking, through the elimination of or reduction in one or more components with negative health effects (e.g., fat reduction or lactose elimination) or through the fortification of milk with ingredients of proven functional value (whey proteins, omega- 3 fatty acids, inulin and probiotics). Contextually, the adaptability of some of the studied technologies to the industrial equipment available in the Sardinian dairy companies was also verified. These novel dairy products have a dual purpose. On one hand, they can meet the current market demand, which shows a greater interest in fresh and short-ripened dairy products, with a low energy intake and a high nutritional value. On the other hand, the technological processes and the obtained products provide examples for dairy companies to boost their market placement and the diversification of sheep and goat dairy production. Naturally, the latter will require investments and strong technological innovations in a sector such as the small ruminants dairy business, which is still largely linked to conventional manufacturing technologies suitable for producing a limited number of traditional cheese varieties.

Supplementary Materials: The following material is available online at http://www.mdpi.com/2624-862X/1/2/10/s1, Figure S1: Process flow diagram of lactose-free Ricotta cheese production, Figure S2: Process flow diagram of short-ripened goat milk cheese production with the addition of microparticulated whey proteins (MWP) obtained from a commercial whey protein concentrate (WPC); Figure S3: Process flow diagram of soft sheep milk cheese production with the addition of microparticulated whey proteins (MWP) obtained from sweet sheep whey; Figure S4: Process flow diagram of fresh goat milk cheese production with a predetermined composition and different fat contents; Figure S5: Process flow diagram of fresh goat milk cheese production with a predetermined composition obtained by replacing fat with inulin in different amounts; Figure S6: Process flow diagram of functional product manufacturing with a predetermined composition of goat milk.

Author Contributions: Conceptualization, A.P. and M.P.; methodology, G.L., M.P., M.A. and A.P.; validation, G.L., M.P., M.A. and A.P.; investigation, G.L. and M.P.; writing-original draft preparation, G.L. and M.P.; writing-review and editing, A.P. and M.A.; supervision, A.P.; project administration, A.P.; funding acquisition, A.P. All authors have read and agreed to the published version of the manuscript.

Funding: This research was funded by Sardegna Ricerche, "Diversification in sheep \& goat Sardinian dairy production"-POR-FESR, Sardinia, 2014-2020, Research and Innovation, Axis 1.

Acknowledgments: The technical staff of both the Technology and Chemistry sectors of Agris Sardegna and Associazione Regionale Allevatori (ARA) Sardegna are gratefully acknowledged.

Conflicts of Interest: The authors declare no conflict of interest.

\section{References}

1. Bigliardi, B.; Galati, F. Innovation trends in the food industry: The case of functional foods. Trends Food Sci. Technol. 2013, 31, 118-129. [CrossRef]

2. Annunziata, A.; Vecchio, R. Functional foods development in the European market: A consumer perspective. J. Funct. Foods 2011, 3, 223-228. [CrossRef]

3. Galland, L. Functional foods: Health effects and clinical applications. In Encyclopedia of Human Nutrition; Allen, L.H., Prentice, A., Caballero, B., Eds.; Academic Press: Waltham, MA, USA, 2013; Volume 2, pp. 366-370. ISBN 978-0-12-384885-7.

4. Regulation (EC) No 1924/2006 of the European Parliament and of the Council of 20 December 2006 on Nutrition and Health Claims Made on Food. Available online: http://eurlex.europa.eu/legal-content/EN/ ALL/?uri=CELEX\%3A02006R1924-20121129 (accessed on 19 March 2020).

5. EU Register of Nutrition and Health Claims Made on Foods. Available online: https://ec.europa.eu/food/ safety/labelling_nutrition/claims/register/public/ (accessed on 6 May 2020).

6. Aliakbarian, B.; Casale, M.; Paini, M.; Casazza, A.A.; Lanteri, S.; Perego, P. Production of a novel fermented milk fortified with natural antioxidants and its analysis by NIR spectroscopy. LWT Food Sci. Technol. 2015, 62, 376-383. [CrossRef]

7. Al-Sheraji, S.H.; Ismail, A.; Manap, M.Y.; Mustafa, S.; Yusof, R.M.; Hassan, F.A. Prebiotics as functional foods: A review. J. Funct. Foods 2013, 5, 1542-1553. [CrossRef]

8. Özer, B.H.; Kirmaci, H.A. Functional milks and dairy beverages. Int. J. Dairy Technol. 2013, 63, 1-15. [CrossRef]

9. Albenzio, M.; Santillo, A.; Avondo, M.; Nudda, A.; Chessa, S.; Pirisi, A.; Banni, S. Nutritional properties of small ruminant food products and their role on human health. Small. Rumin. Res. 2016, 135, 3-12. [CrossRef] 
10. Ortiz, Y.; García-Amézquita, E.; Acosta, C.H.; Sepúlveda, D.R. Functional Dairy Products. In Global Food Security and Wellness; Barbosa-Cánovas, G., Pastore, G., Candoğan, K., Medina Meza, I.G., Caetano Da Silva Lannes, S., Buckle, K., Yada, R., Rosenthal, A., Eds.; Springer: New York, NY, USA, 2017; pp. 67-103. ISBN 978-1-4939-6496-3.

11. Gille, D.; Walther, B.; Badertscher, R.; Bosshart, A.; Brügger, C.; Brühlhart, M.; Gauch, R.; Noth, P.; Vergères, G.; Egger, L. Detection of lactose in products with low lactose content. Int. Dairy J. 2018, 83, 17-19. [CrossRef]

12. Suri, S.; Kumar, V.; Prasad, R.; Tanwar, B.; Goyal, A.; Kaur, S.; Gat, Y.; Kumar, A.; Kaur, J.; Singh, D. Considerations for development of lactose-free food. J. Nutr. Intermed. Metab. 2019, 15, 27-34. [CrossRef]

13. Ministero Della Salute. Nota Esplicativa Della Direzione Generale Igiene e Sicurezza Alimenti e Nutrizione, Ufficio IV del 7/07/2015. Available online: http://www.salute.gov.it/portale/news/p3_2_1_1_1.jsp?lingua= italiano\&menu=notizie\& $\mathrm{p}=$ dalministero\&id=2180 (accessed on 24 March 2020).

14. Dekker, P.J.T.; Koenders, D.; Bruins, M.J. Lactose-Free Dairy Products: Market Developments, Production, Nutrition and Health Benefits. Nutrients 2019, 11, 551. [CrossRef]

15. Mucchetti, G.; Neviani, E. Microbiologia e Tecnologia Lattiero-Casearia. Qualità e Sicurezza; Tecniche Nuove: Milan, Italy, 2006; pp. 363-382. ISBN 978-88-481-1817-0.

16. Salvatore, E.; Pes, M.; Falchi, G.; Pagnozzi, D.; Furesi, S.; Fiori, M.; Roggio, T.; Addis, M.F.; Pirisi, A. Effect of whey concentration on protein recovery in fresh ovine ricotta cheese. J. Dairy Sci. 2014, 97, 4686-4694. [CrossRef]

17. Bosso, A.; Morioka, L.R.I.; dos Santos, L.F.; Suguimoto, H.H. Lactose hydrolysis potential and thermal stability of commercial $\beta$-galactosidase in UHT and skimmed milk. Food Sci. Technol. 2016, 36, 159-165. [CrossRef]

18. Ustok, F.I.; Tari, C.; Harsa, S. Biochemical and thermal properties of $\beta$-galactosidase enzymes produced by artisanal yoghurt cultures. Food Chem. 2010, 119, 1114-1120. [CrossRef]

19. Coulston, A.M.; Boushey, C.J. Nutrition in the Prevention and Treatment of Disease, 2nd ed.; Academic Press: London, UK, 2008; pp. 469-479. ISBN 978-0123741189.

20. Gazzetta Ufficiale Della Repubblica Italiana, Legge 19 Febbraio 1992, n. 142. Available online: https: //www.gazzettaufficiale.it/eli/id/1992/03/05/092A1068/sg (accessed on 27 March 2020).

21. Mohamed, A.G. Low-Fat Cheese: A Modern Demand. Int. J. Dairy Sci. 2015, 10, 249-265. [CrossRef]

22. El-Bakry, M.; Sanchez, A.; Mehta, B.M. Microstructure of Dairy Products, 1st ed.; John Wiley \& Sons Ltd: Chichester, UK, 2019; pp. 145-171. ISBN 978-1118964224.

23. Banks, J.M. The technology of low-fat cheese manufacture. Int. J. Dairy Technol. 2004, 57, 199-207. [CrossRef]

24. Ipsen, R. Microparticulated whey proteins for improving dairy product texture. Int. Dairy J. 2017, 67, 73-79. [CrossRef]

25. Schenkel, P.; Samudrala, R.; Hinrichs, J. The effect of adding whey protein particles as inert filler on thermophysical properties of fat-reduced semihard cheese type Gouda. Int. J. Dairy Technol. 2013, 66, 220-230. [CrossRef]

26. Liu, K.; Stieger, M.; van der Linden, E.; van de Velde, F. Effect of microparticulated whey protein on sensory properties of liquid and semi-solid model foods. Food Hydrocoll. 2016, 60, 186-198. [CrossRef]

27. Sánchez-Obando, J.; Cabrera-Trujillo, M.; Olivares-Tenorio, M.; Klotz, B. Use of optimized microparticulated whey protein in the process of reduced-fat spread and petit-suisse cheeses. LWT Food Sci. Technol. 2020, 120, 108933. [CrossRef]

28. Smithers, G.W. Whey and whey proteins-From 'gutter-to-gold': A review. Int. Dairy J. 2008, 18, 695-704. [CrossRef]

29. Sturaro, A.; Penasa, M.; Cassandro, M.; Varotto, A.; De Marchi, M. Effect of microparticulated whey proteins on milk coagulation properties. J. Dairy Sci. 2014, 97, 6729-6736. [CrossRef]

30. Stankey, J.A.; Lu, Y.; Abdalla, A.; Govindasamy-Lucey, S.; Jaeggi, J.J.; Ø Mikkelsen, B.; Pedersen, K.T.; Andersen, C.B. Low-fat Cheddar cheese made using microparticulated whey proteins: Effect on yield and cheese quality. Int. J. Dairy Technol. 2017, 70, 481-491. [CrossRef]

31. Pes, M.; Addis, M.; Salvatore, E.; Furesi, S.; Di Salvo, R.; Pirisi, A. Tecnologia alternativa di fabbricazione di un formaggio caprino a pasta fresca. Sci. Tecn. Latt-Cas. 2014, 65, 159-174.

32. Kumar, R.; Chauhan, S.K.; Shinde, G.; Subramanian, V.; Nadanasabapathi, S. Whey Proteins: A potential ingredient for food industry-A review. Asian J. Dairy Food Res. 2018, 37, 283-290. 
33. CREA —Consiglio Per la Ricerca in Agricoltura e L'analisi Dell'economia Agraria; Tabelle di Composizione Degli Alimenti. Available online: https://www.alimentinutrizione.it/ (accessed on 6 April 2020).

34. Peng, X.; Yao, Y. Carbohydrates as fat replacers. Annu. Rev. Food Sci. T. 2017, 8, 331-351. [CrossRef]

35. Karimi, R.; Azizi, M.H.; Ghasemlou, M.; Vaziri, M. Application of inulin in cheese as prebiotic, fat replacer and texturizer: A review. Carbohydr. Polym. 2015, 119, 85-100. [CrossRef]

36. Shoaiba, M.; Shehzad, A.; Omar, M.; Rakha, A.; Raza, H.; Sharif, H.R.; Shakeel, A.; Ansari, A.; Niazi, S. Inulin: Properties, health benefits and food applications: A review. Carbohydr. Polym. 2016, 147, 444-454. [CrossRef]

37. Meyer, D.; Bayarri, S.; Tárrega, A.; Costell, E. Inulin as texture modifier in dairy products. Food Hydrocoll. 2011, 25, 1881-1890. [CrossRef]

38. Salvatore, E.; Pes, M.; Mazzarello, V.; Pirisi, A. Replacement of fat with long-chain inulin in a fresh cheese made from caprine milk. J. Dairy Sci. 2014, 34, 1-5. [CrossRef]

39. World Health Organization; Food and Agriculture Organization of the United Nations. Guidelines on Food Fortification with Micronutrients; Allen, L., de Benoist, B., Dary, O., Hurrell, R., Eds.; World Health Organization: Geneva, Switzerland, 2006; pp. 26-27. ISBN 92-4-159401-2.

40. Bütikofer, U.; Meyer, J.; Rehberger, B. Determination of the percentage of alpha-lactalbumin and beta-lactoglobulin of total milk protein in raw and heat treated skim milk. Milchwissenschaft 2006, 61, 263-266.

41. Marshall, K. Therapeutic applications of whey protein. Altern. Med. Rev. 2004, 9, 136-156.

42. Patel, S. Functional food relevance of whey protein: A review of recent findings and scopes ahead. J. Funct. Foods 2015, 19, 308-319. [CrossRef]

43. Swanson, D.; Block, R.; Mousa, S.A. Omega-3 fatty acids EPA and DHA: Health benefits throughout life: A review. Adv. Nutr. 2012, 3, 1-7. [CrossRef] [PubMed]

44. Punia, S.; Sandhu, K.S.; Siroha, A.K.; Dhull, S.B. Omega 3-metabolism, absorption, bioavailability and health benefits-A review. J. Pharm. Nutr. Sci. 2019, 10,1-28. [CrossRef]

45. Food and Agriculture Organization of the United Nations (FAO). Fats and Fatty Acids in Human Nutrition: Report of an Expert Consultation; FAO, Food and Nutrition Paper: Rome, Italy, 2010; pp. 9-20. ISBN 978-92-5-106733-8.

46. Kolanowski, W.; Laufenberg, G. Enrichment of food products with polyunsaturated fatty acids by fish oil addition. Eur. Food Res. Technol. 2006, 222, 472-477. [CrossRef]

47. Kolanowski, W.; Weissbrodt, J. Sensory quality of dairy products fortified with fish oil. Int. Dairy J. 2007, 17, 1248-1253. [CrossRef]

48. Bermúdez-Aguirre, D.; Barbosa-Cánovas, G.V. Fortification of queso fresco, cheddar and mozzarella cheese using selected sources of omega-3 and some nonthermal approaches. Food Chem. 2012, 133, 787-797. [CrossRef]

49. Food and Agricultural Organization of the United Nations; World Health Organization. Probiotics in Food: Health and Nutritional Properties and Guidelines for Evaluation; FAO, Food and Nutrition Paper: Rome, Italy, 2006; pp. 1-2. ISBN 92-5-105513-0.

50. Hill, C.; Guarner, F.; Reid, G.; Gibson, G.R.; Merenstein, D.J.; Pot, B.; Morelli, L.; Canani, R.B.; Flint, H.J.; Salminen, S.; et al. Expert consensus document. The International Scientific Association for Probiotics and Prebiotics consensus statement on the scope and appropriate use of the term probiotic. Nat. Rev. Gastroenterol. Hepatol. 2014, 11, 506-514. [CrossRef]

51. Kerry, R.G.; Patra, J.K.; Gouda, S.; Park, Y.; Shin, H.S.; Das, G. Benefaction of probiotics for human health: A review. J. Food Drug Anal. 2018, 26, 927-939. [CrossRef]

52. Ministero Della Salute. Direzione Generale per l'Igiene e la Sicurezza degli Alimenti e la Nutrizione. Linee Guida su Probiotici e Prebiotici, Revisione Marzo 2018. Available online: http://www.salute.gov.it/ imgs/C_17_pubblicazioni_1016_allegato.pdf (accessed on 8 April 2020).

53. Pes, M.; Addis, M.; Lai, G.; Fiori, M.; Paba, A.; Comunian, R.; Furesi, S.; Pirisi, A. Formulazione di un nuovo prodotto funzionale da latte di capra. Sci. Tecn. Latt-Cas. 2016, 67, 5-22.

54. Commission Regulation (EU) No 116/2010 of 9 February 2010 amending Regulation (EC) No 1924/2006 of the European Parliament and of the Council with Regard to the List of Nutrition Claims. Available online: https://eur-lex.europa.eu/legal-content/en/ALL/?uri=CELEX:32010R0116 (accessed on 8 April 2020).

(C) 2020 by the authors. Licensee MDPI, Basel, Switzerland. This article is an open access article distributed under the terms and conditions of the Creative Commons Attribution (CC BY) license (http://creativecommons.org/licenses/by/4.0/). 